\section{ELECTROMAGNETIC WAVES IN METAL TUBES OF RECTANGULAR CROSS-SECTION}

A $\mathrm{N}$ article by J. Kemp (Electrical Communication, A 20, No. 2, 1941) shows how the attenuation of electromagnetic waves propagated through the interior of rectangular metal tubes is calculated by the familiar telephone transmission formula, the top and bottom of the tube being regarded as zigzag flat-strip transmission lines while the side walls, when suitably disposed, are regarded as transmission lines of another type. From the losses occurring in these lines, the attenuation offered by the tube is obtained in a simple manner. The general formula for the attenuation of all types of waves in metal tubes of all cross-sections has been established by Schelkunoff. Chu and Barrow have also derived attenuation formulæ for all types of waves supported by tubes of rectangular cross-section. The method. so far followed has involved the computation of the energy flow in the direction of the tube and the power losses in the walls by means of the Poynting flux theorem.

Electromagnetic waves in metal tubes are characterized by two essential features. There is a minimum frequency below which no waves are supported by the tube. This minimum or cut-off frequency is determined by the shape and the size of the tube. As the wave-length of the cut-off frequency is of the order of the cross-sectional dimension of the tube, the frequencies of the possible waves-for air-filled tubes having dimensions in the centimetre rangeare of the order of $10^{\circ} \mathrm{c} . / \mathrm{s}$. and above.

The second feature is that there is either an electric or a magnetic intensity in the direction of propagation of the waves, that is, along the tube. For electromagnetic waves in free space the electric and the magnetic intensities are in planes at right angles to the direction of propagation. When, however, waves are restricted to the inside of metal tubes there is, in addition to the electric and magnetic intensities of the free-space waves, either an electric or a magnetic intensity in the direction of propagation. It is customary to use this additional property of these waves for their classification. When there is an electric intensity in the direction of propagation, the wave is designated an $E$-wave. When there is a magnetic intensity in the direction of propagation, the wave is designated an $H$-wave.

The article proceeds to the mathematics of the problem and it is shown that the method reveals the existence of a link between two seemingly disjointed branches of telecommunication: (1) telecommunication of the classical character, employing a 'circuit', that is, a system comprising a 'go' and a 'return' path, and (2) telecommunication through hollow metal tubes without a return path in the conventional sense. The final expression for the attenuation constant of waves propagated through hollow metal tubes is derived in a simple manner from the familiar equations for the attenuation of telephone lines, with due regard to the reflexion loss at the junction of dissimilar lines, and the numerical results obtained by the shortened method agree in every respect with those obtained by more elaborate means by other investigators. The simplicity of the method arises from the fact that the telephone transmission formulæ contain implicitly the concepts required in the detailed calculation by orthodox procedure.

\section{FORTHCOMING EVENTS}

Wednesday, July 8

Institute of Physios (EIrectronics Group) (at the Royal Institution, 21 Albemarle Street, London, W.1), at 5 p.m.-Discussion on "Cathode Ray Tubes".

Thursday, July 9

Ifstitute of SEWAGE PURTrication (at Friends House, Euston Road, London, N.W.1), at 2.30 p.m.-Dr. E. M. Crowther : "The Maanurial Value of Sewage Sludges". Mr. H. M. Crowther: The
Review of Recent Work on Sewage Filtration". July 10 (mortitical Visit to Rothamsted Experimental Station, Harpenden, Herts.

Friday, July 10

SOCIETY OF CHeMrCAL INDUSTRY (at the Royal Institution, Albemarle Street, London, W.1) at 2.30 p.m.-Annual General Meeting; at 3 p.m.--Presidential Àddress.

RoYaI Astronomtcar Socxery (at Burlington House, Piccadilly, London, W.1), at 4.30 p.m.-Discussion on "The Structure and Rotation of Galaxies" (to be opened by Dr. A. Hunter, Dr. H. A. Briïck, Si Arthur Eddington, O.M., F.R.S., Dr. H. Spencer Jones, F.R.S.).

\section{APPOINTMENTS VACANT}

APPLICATrons are invited for the following appointments on or before the dates mentioned :

Head DF THE BuLding Department of the Croydon PolytechnicThe Education Officer, Eduration Offlce, Katherine Street, Croydon (July 9)

IECTGRER (WOMAN) IN PHystology, ANATOMY AND HYGIENe at the Dunfermline College of Hyglene and Physical Education-The Fxecutive Officer, National Committee for the Training of Teachers, 140 Princes Street, Edinburgh 2 (July 10).

ImCturer In Physics-The Principal, Royal Technical College, Salford (July 10).

VETERINARY INVESTIGATION OFFICRR-The Secretary, West of Scotland Agricultural College, 6 Blythswood Square, Glasgow (July 10) Trachre of ENGINeERINa StrbJects at the Redditch Technical School-The Secretary to the Worcestershire Education Committee, Education Office, Church Green West, Redditch (July 11).

GRADUATE ASSISTANT Mistrmss to teach General Science including Biology and Geography-The Principal, Technical Institute, Tun bridge Wells (July 13). GRADUATE LECTURER IN MECFANICAL ENGINEERING SUBJECTS at
the Denbighshire Technical Institute. Wrexham-The Director of the Denbighshire Technical Institute, Wrexham

LEOTURER IN PHYSICS (MAN OR WOMAN)-The Registrar, North Gloucestershire Technical College, Cheltenham (July 13).

IECTCRER IN Colodring MatTors-The Registrar, College of Technology, Manchester 1 (July 13).

VETERINARY BACTERIOLOGIST-The Registrar, King's College, Newcastle-upon-Tyne 2 (July 20).

WATER ENGINER AND MANAGER to the Corporation of SwanseaThe Town Clerk, The Guildhall, Swansea (July 20).

ASSISTANT FOR WORKSHOP AND GENERAL ENGINEERTNG SEBJEOTS -The Principal, Erith Technical College, Belvedere, Erith, Kent.

\section{REPORTS and other PUBLICATIONS}

(not included in the monthly Books Supplement) Great Britain and Ireland

Ross Institute of Tropical Hygiene. Some Emergency Anti-Malarial Ross Institute of Tropical Hygiene. Some Emergency Anti-Malarial
Measures. Bv Sir Malcolm Watson. Pp. $8+8$ plates. (London : Ross Measures. Bv Sir Malcolm Watson. Pp. $8+8$ plates. (London : Ross
Institute of Tropical Hyglene.) Annual Report of the Titzwilliam Museum Syndicate for the Year 1941. Pp. 10. (Cambridge: Fitzwilliam Museum.)
[226 Friends of the Fitzwilliam Museum. Thirty-third Annual Report for the Year 1941. Pp. 4. (Cambridge: Fitzwilliam Museum.) [226

\section{Other Countries} Air Department: New Zealand Meteorological Office. Professional
Note No. 1: Synoptic Analysis over the Southern Oceans. By Note No. 1: Synoptic Analysis over the Southern Oceans. By
C. E. Palmer. Pp. iv $+38+39$ plates. (Wellington: Meteorological C. E. Palmer. Pp. iv $+38+39$ plates. (Wellington: Meteorological
Office.)

Forest Research in India, 1940-41. Part 2: Reports for Burma and Indian Provinces. Pp. iii +242. (Dehra Dun: Manager of Publications.) 3.12 rupees : 68 .
[176 Records of the Geological Survey of India. Vol. 75, Professional Paper No. 15: The Charnockite Series of Bastar State and Western Jeypore. By P. K. Ghosh. Pp. iil $+55+$ vili +8 plates. (Calcutta: Tupees; 38 . Ud. Friation of the Variation of the Electrical Resigtance of Indian Timbers with Moisture Content. By D. Narayanamurti. Pp. iil $+7+5$ plates. (Delhi : Manager
of Publications.) 8 annas; $9 d$. Ontario Research Foundation. Report for the Year 1941. Pp. 25. (Toronto: Ontario Research Foundation.) 